\title{
Carp coccidiosis: clinical and hematological observations of carp infected with Goussia carpelli
}

\author{
D. Steinhagen*, B. Oesterreich, W. Körting
}

Fachgebiet Fischkrankheiten und Fischhaltung, Tierärztliche Hochschule Hannover, Bünteweg 17, D-30559 Hannover, Germany

\begin{abstract}
To examine the pathogenic capacity of Goussia carpelli, a gut-dwelling coccidian parasite of common carp Cyprinus carpio, hematological parameters were recorded from carp following a laboratory-induced infection with this parasite. With the development of the parasite, serum sodium and protein levels decreased, thus indicating an ion loss and the hydration of blood plasma in infected fish. On Days 8 and 11 post exposure (PE) to the parasite, Aeromonas spp.-like bacteria were detected in the liver and the spleen of 8 infected carp out of the 10 carp sampled, while uninfected control carp remained bacteria-free. On these dates, infected carp were listless, and their intestines appeared dilated and were filled with a whitish-yellow gelatinous content. In intestinal scrapings, gamogonic and sporogonic developmental stages of the coccidia were found. Differential white blood cell counts of peripheral blood leukocytes showed an increase in granulocyte numbers on Days 11 and $14 \mathrm{PE}$. On Days 21 and 28 PE, when the carp had already excreted most of the oocysts, a clear leucocytosis was found. Owing to the osmotic challenge of infected carp, which is caused by ion loss and plasma hydration, and to the invasion of opportunistic bacteria, the infection of carp with $G$. carpelli should be taken as a serious pathogen affecting stressed or juvenile fish.
\end{abstract}

KEY WORDS: Goussia carpelli $\cdot$ Coccidia $\cdot$ Hematology $\cdot$ Serum electrolytes $\cdot$ Serum proteins $\cdot$ Carp Pathology

\section{INTRODUCTION}

Feral and cultured fish are infected with a wide variety of gut-dwelling parasites which may be responsible for serious disease. Goussia carpelli, a coccidian parasite of common carp Cyprinus carpio L. causes an enteritic coccidiosis (Schäperclaus 1943, Doflein \& Reichenow 1953, Ivassik \& Kulakovskaja 1959) and high mortalities in stocks of carp and goldfish fry (Doflein \& Reichenow 1953, Kent \& Hedrick 1985). The transmission of the parasite to uninfected carp involves fecal contamination and indirect transmission via tubificid oligochaetes (Steinhagen \& Körting 1990). In nature the main source of infection is pond sediment which contains high numbers of infective stages, probably sporulated oocysts (Kocylowski et al. 1976, Steinhagen et al. 1996), and carp fry acquire the parasite when the fish start feeding. In Northern German carp hatcheries, intestines of carp fry harbor merogonic,

•E-mail: dstein@fisch.tiho-hannover.de gamogonic, and sporogonic developmental stages of G. carpelli, 3 to $4 \mathrm{wk}$ post-hatch. In nature, pathological changes of intestinal tissues were observed in carp fry during this time, but not in older populations (Steinhagen et al. 1996). Whether or not the coccidian has to be regarded as a major pathogen for cultivated carp remained unclear.

In laboratory studies, Goussia carpelli caused severe epithelium losses and a leukocytic infiltration of subepithelial tissues (Jendrysek et al. 1994). These observations led to the conclusion that $G$. carpelli is a coccidian species which is highly pathogenic. To further examine this pathogenic capacity, we recorded hematological parameters from carp with a laboratoryinduced $G$. carpelli infection

\section{MATERIALS AND METHODS}

Carp. For infection experiments, carp of a single crossing $($ E20 $\times$ R8, Wageningen Agricultural Univer- 
sity, The Netherlands) were used. The carp were bred and raised in the laboratory, kept coccidia-free in glass tanks filled with tap water and were fed with commercial fish feed (Trouvit, The Netherlands).

Infection experiments. Carp 7 and 12 mo old and with a body weight of $30( \pm 5)$ and $50( \pm 5) \mathrm{g}$, respectively, were infected with Goussia carpelli as described previously (Steinhagen \& Körting 1988). The fish were placed in a tank contaminated with oocysts, kept there for 24 to $48 \mathrm{~h}$ and then transferred to $80 \mathrm{l}$ glass tanks at a temperature of 20 to $24^{\circ} \mathrm{C}$. For controls, uninfected carp were kept in separate tanks under identical conditions. Swimming activity and food uptake of infected and control carp was observed and scored on an arbitrary scale during the development of the parasite. In 2 experiments, blood and tissues were sampled on Days 5, 8 , $11,14,17$, and 20 post exposure (PE) to the parasite from 4 infected and 4 non-infected control carp and on Days $7,14,21,28,35$, and 49 PE from 5 infected and 5 uninfected carp.

Blood and tissue samples. For blood samples, carp were anesthetized in $0.02 \%$ benzocaine (MS 222, Sandoz, Basel) and peripheral blood was drawn from the caudal vessel into a disposable $1 \mathrm{ml}$ syringe with a heparinized $0.90 \times 40 \mathrm{~mm}$ needle, transferred into $5 \mathrm{ml}$ glass tubes and allowed to clot for $15 \mathrm{~min}$ at room temperature $\left(20\right.$ to $\left.24^{\circ} \mathrm{C}\right)$. After centrifugation $(300 \times g$, $10 \mathrm{~min}$ ), the serum was removed from the blood clot and stored frozen at $-25^{\circ} \mathrm{C}$. Additionally, blood was collected in 2 heparinized micro-hematocrit tubes (Brand, Germany). To detect an infection of internal organs with bacteria, the carp were killed and material from dissected liver and spleen was inoculated into blood agar plates. The plates were incubated at room temperature for $48 \mathrm{~h}$ and then monitored for growth of bacteria colonies. To confirm that the carp were infected with the parasite, and to observe the parasite's development, fresh and Giema-stained gut smears were examined.

Hematological methods. Determination of packed cell volume (PCV), red blood cell counts (RBC), total, and differential white blood cell (WBC) counts were performed using standard methods (Houston 1990). The osmolarity of serum samples was measured using a cryo-osmometer (Vogel, Gießen, Germany). Potassium and sodium levels were determined with a flame photometer (Ciba Corning Diagnostics, Germany). Total serum protein and serum albumin levels were analyzed by the biuret reaction method (Weichselbaum 1946) and measured with a photometer (Hitachi, Japan). These measurements were used to calculate the serum globulin levels and the albumin/globulin ration of the serum samples. Serum proteins were separated electrophoretically on cellulose acetate plates, stained with Ponceau S (Sigma Chemicals, St. Louis, $\mathrm{MO}$, USA) and analyzed with a densitometer (Bender \& Hobein, München, Germany).

Statistical methods. The data were analyzed by 1 -way analysis of variance. Differences were considered to be significant at $p<0.05$.

\section{RESULTS}

\section{Development of the coccidia}

Intestinal scrapings of infected carp harbored merogonic developmental stages on Days 5 and 7, gamogonic and sporogonic stages on Day 8 , and oocysts on Days 11, 14, and 17 PE. Few or no coccidia were found on Days 20 to $49 \mathrm{PE}$

Carp from the uninfected control group remained coccidia-free throughout the experiments.

Infected carp refused to feed from Days 8 to $17 \mathrm{PE}$; their intestines appeared dilated and filled with a whitish-yellow gelatinous content. From Days 11 to 14 $\mathrm{PE}$, the general appearance of infected carp was inappetent, but no fish died. The carp started to feed again by Days 17 to 20. At later dates there was no difference in the behavior of infected carp compared to uninfected control fish.

On Days 8 and $11 \mathrm{PE}$, infected carp had an enlarged spleen and Aeromonas spp. infections could be detected in the spleen and liver of 8 infected carp out of the 10 carp sampled. No bacteria were found in tissues of parasitized carp on Day 5 PE, on Days 14 to 49 PE, or in samples from uninfected control carp throughout the experiment.

\section{Hematology}

With the development of the parasite Goussia carpelli in the intestine of infected carp, an increase in the number of WBC could be observed in the peripheral blood of parasitized carp. In the peripheral blood of control carp about $28 \times 10^{3} \mathrm{WBC} \mathrm{mm}^{-3}$ were countedi parasitized carp showed a clear leucocytosis on Days 21 and $28 \mathrm{PE}$ with more than $40 x$ $10^{3} \mathrm{WBC} \mathrm{mm}^{-3}$ blood ( $\mathrm{p}<0.05$ ), and elevated numbers of leukocytes on Day $35 \mathrm{PE}$ (Fig. 1). By these dates, the fish had already excreted the majority of oocysts and only single parasites were found in gut smears. In differential WBC counts, the proportion of granulocytes was elevated during the period of gamogony and oocyst formation of the parasite on Days 11 and 14 PE, but no differences could be observed on Days 17 and $20 \mathrm{PE}$ (Table 1) or on Days 21 to $49 \mathrm{PE}$ (data not shown). 


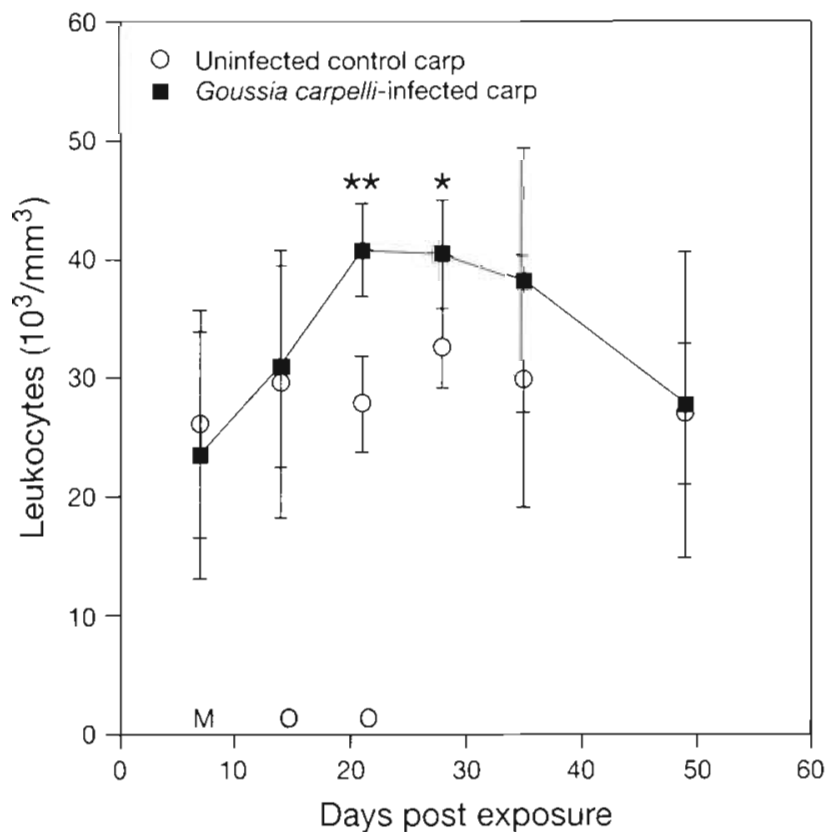

Fig. 1. Cyprinus carpio. White blood cell counts in the peripheral blood of carp infected with Goussia carpelli. Each data point represents mean and standard deviation from 5 individual carp. $\mathrm{M}$ : meronts; $\mathrm{O}$ : sporonts and oocysts in mucosal smears. Differences between infected and uninfected control carp at $" p<0.05$ and at $\cdots p<0.01$. Depicted are results of 1 out of 2 experiments
The PCV, the number of RBC and the relative number of reticulocytes did not change in the blood of parasitized carp throughout the experiment (Table 2).

\section{Serum electrolytes}

During the development of Goussia carpelli, clear changes of serum electrolytes occurred in infected carp. In uninfected carp, the serum sodium level was $146.5 \pm 3.6 \mathrm{mmol}^{-1}$. During merogony and oocyst formation of the parasite on Days 8,11, and $14 \mathrm{PE}$, the concentration of sodium dropped up to $134.13 \mathrm{mmol} \mathrm{l}^{-1}$ (Day 11) and $129.38 \mathrm{mmol}^{-1}$ (Day 14). On Days 17 and $20 \mathrm{PE}$, by which time most oocysts had already been excreted, the sodium concentration returned to the level of the control fish (Fig. 2). Serum levels of potassium increased from $0.72 \mathrm{mmol} \mathrm{l}^{-1}$ in uninfected controls to more than $2.0 \mathrm{mmol} \mathrm{l}^{-1}$ during oocyst formation on Days 11, 14, 17, and 20 PE, but dropped to the level of control fish in long-term observations (Fig. 3).

The osmolarity of serum samples varied in individual fish within a wide range between 270 and $303 \mathrm{mOsm}$ $\mathrm{kg}^{-1}$, which made it difficult to detect the influence of coccidiosis. On Days 11 and 14 PE, however, serum osmolarity in samples from infected carp were slightly lower than in control carp (Fig. 4).

Table 1. Cyprinus carpio. Differential white blood cell counts in the periperal blood of carp with Goussia carpelli infection. Given are mean \pm standard deviation of relative numbers white blood cell populations from 4 carp. PE: post exposure to the parasite. Presented are results of 1 out of a set of 2 experiments

\begin{tabular}{|rcccccc}
\hline \multirow{2}{*}{$\begin{array}{c}\text { Days } \\
\text { PE }\end{array}$} & \multicolumn{2}{c}{ Lymphocytes } & \multicolumn{2}{c}{ Granulocytes } & \multicolumn{2}{c}{ Monocytes } \\
& Controls & Infected & Controls & Infected & Controls \\
\hline 5 & $85.5 \pm 3.4$ & $90.5 \pm 6.6$ & $12.8 \pm 2.1$ & $8.0 \pm 7.7$ & $1.8 \pm 1.5$ & $1.5 \pm 1.3$ \\
8 & $92.0 \pm 4.3$ & $90.5 \pm 5.6$ & $6.8 \pm 4.3$ & $8.5 \pm 4.7$ & $1.3 \pm 1.0$ & $1.0 \pm 1.2$ \\
11 & $91.8 \pm 3.4$ & $81.3 \pm 9.7$ & $8.3 \pm 3.7$ & $17.3 \pm 8.9$ & $0.3 \pm 0.5$ & $1.3 \pm 1.0$ \\
14 & $93.5 \pm 3.5$ & $76.8 \pm 18.1$ & $5.0 \pm 2.6$ & $23.0 \pm 17.0$ & $0.8 \pm 1.0$ & $0.3 \pm 0.5$ \\
17 & $93.0 \pm 6.0$ & $89.8 \pm 9.0$ & $5.8 \pm 4.1$ & $9.5 \pm 9.3$ & $0.5 \pm 0.6$ & $0.8 \pm 1.0$ \\
20 & $90.3 \pm 3.5$ & $95.5 \pm 3.1$ & $9.1 \pm 3.1$ & $3.5 \pm 2.4$ & $0.3 \pm 0.5$ & $0.8 \pm 0.5$ \\
& & & & & & \\
\hline
\end{tabular}

Table 2. Cyprinus carpio. Hematocrit and erythrocyte counts in the peripheral blood of carp with Goussia carpelli infection. Given are mean \pm standard deviation of measurements from 4 individual carp. PE: post exposure to the parasite. Presented are results of 1 out of a set of 2 experiments

\begin{tabular}{|c|c|c|c|c|c|c|}
\hline \multirow{2}{*}{$\begin{array}{c}\text { Days } \\
\text { PE }\end{array}$} & \multicolumn{2}{|c|}{ Hematocrit (\%) } & \multicolumn{2}{|c|}{ Erythrocytes $\left(10^{6} \mathrm{ml}^{-1}\right)$} & \multicolumn{2}{|c|}{ Reticulocytes $(\%)$} \\
\hline & Controls & Infected & Controls & Infected & Controls & Infected \\
\hline 5 & $25.8 \pm 6.3$ & $33.5 \pm 6.2$ & $1.6 \pm 0.3$ & $1.5 \pm 0.3$ & $1.1 \pm 0.4$ & $1.3 \pm 0.7$ \\
\hline 8 & $25.8 \pm 4.9$ & $31.3 \pm 3.2$ & $1.5 \pm 0.2$ & $1.5 \pm 0.2$ & $1.0 \pm 0.2$ & $0.8 \pm 0.2$ \\
\hline 11 & $30.0 \pm 3.5$ & $33.5 \pm 3.4$ & $1.5 \pm 0.3$ & $2.0 \pm 0.2$ & $0.6 \pm 0.2$ & $0.5 \pm 0.4$ \\
\hline 14 & $31.3 \pm 3.5$ & $33.5 \pm 3.9$ & $1.6 \pm 0.2$ & $1.5 \pm 0.2$ & $1.2 \pm 0.9$ & $1.1 \pm 0.9$ \\
\hline 17 & $34.5 \pm 4.1$ & $33.3 \pm 5.7$ & $1.5 \pm 0.3$ & $1.6 \pm 0.2$ & $2.1 \pm 1.2$ & $0.9 \pm 0.5$ \\
\hline 20 & $30.0 \pm 1.2$ & $31.5 \pm 3.3$ & $1.6 \pm 0.2$ & $1.5 \pm 0.2$ & $1.6 \pm 0.5$ & $0.8 \pm 0.5$ \\
\hline
\end{tabular}




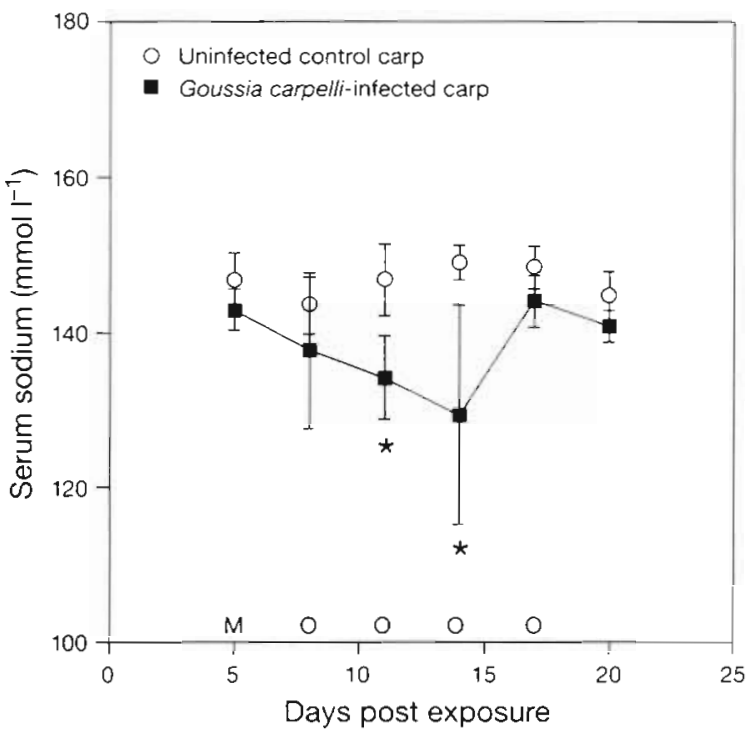

Fig. 2. Cyprinus carpio. Sodium level in the serum of Goussia carpelli-infected carp. Each data point represents mean and standard deviation from 4 individual carp. $M$ : meronts; $O$ : sporonts and oocysts in mucosal smears. Differences between infected and uninfected control carp at $p<0.05$. Depicted are results of 1 out of a set of 3 experiments

\section{Serum proteins}

In the blood of infected carp, the level of serum proteins decreased with the development of the parasite and, compared to the level of the controls $(2.6 \pm 0.2 \mathrm{~g}$

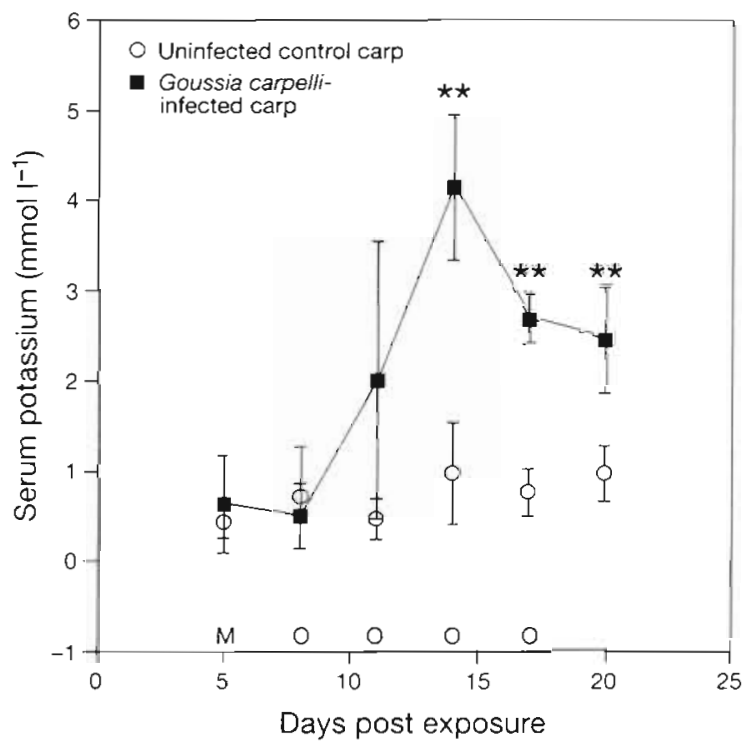

Fig. 3. Cyprinus carpio. Potassium level in the serum of Goussia carpelli-infected carp. Mean and standard deviation from 4 individual carp. $\mathrm{M}$ : meronts; $\mathrm{O}$ : sporonts and oocysts in mucosal smears. Differences between infected and uninfected control carp at $\cdots p<0.01$. Depicted are results of 1 out of 2 experiments

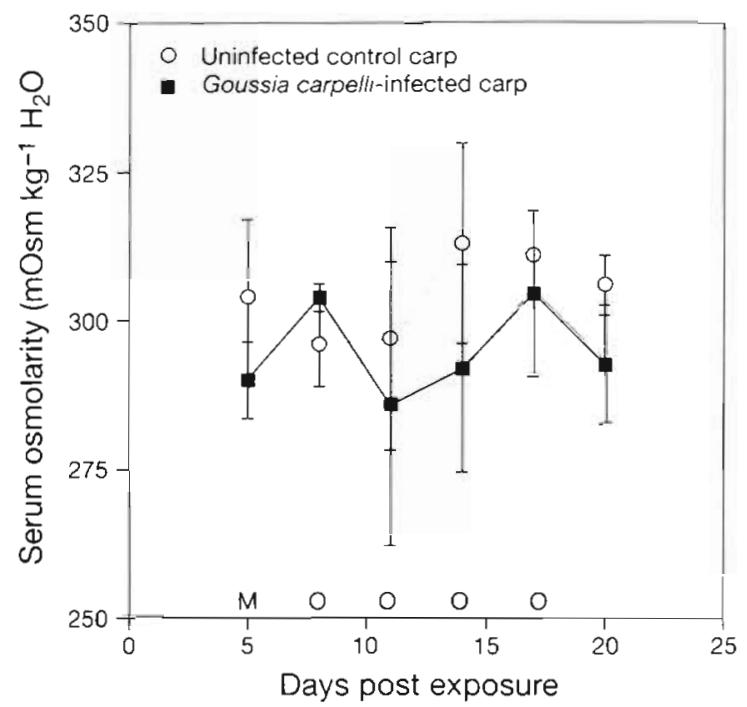

Fig. 4. Cyprinus carpio. Serum osmolarity in the peripheral blood of carp infected with Goussia carpelli. Mean and standard deviation from 4 individual carp form 1 out of a set of 2 experiments. $M$ : meronts; $\mathrm{O}$ : sporonts and oocysts in mucosal smears

$\left.\mathrm{dl}^{-1}\right)$, it was significantly $(\mathrm{p}<0.05)$ lower on Days 11 , 14, 17, and $20 \mathrm{PE}\left(1.64 \pm 0.44 \mathrm{~g} \mathrm{dl}^{-1}\right.$ on Day $14 \mathrm{PE}_{i}$ Fig. 5). This decrease was mainly caused by a reduction of the level of albumins (Fig. 5). By means of cellulose acetate electrophoresis, serum proteins from carp used in infection experiments could be separated into

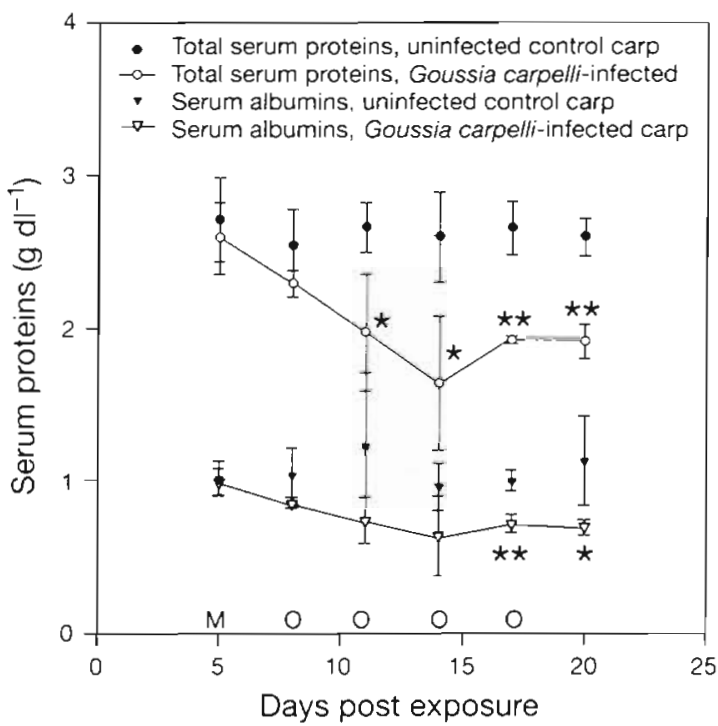

Fig. 5. Cyprinus carpio. Serum protein levels in the blood of Goussia carpelli-infected carp. Mean and standard deviation from 4 individual carp. $M$ : meronts; $O$ : sporonts and oocysts in mucosal smears. Differences between infected and uninfected control carp at $p<0.05$ and at $\cdot p<0.01$. Depicted are results of 1 out of 2 experiments 
3 fractions. Samples from infected and uninfected carp showed a similar banding pattern with 3 clear bands. The densitometric analysis of the bands did not reveal any differences in protein fractions between infected and uninfected carp (data not shown).

\section{DISCUSSION}

In mammalian and avian hosts, the major pathogenic effects of enteritic coccidiosis are blood loss, dehydration due to diarrhea, and invasion by opportunistic microbial pathogens (Gregory 1990). For freshwater fishes, which live in an hypotonic aquatic environment, liquid loss is not as serious as it is for terrestrial animals. Instead, such fishes are threatened by an influx of water, which enters across all permeable surfaces like gill lamellae and oral mucosa, or by ion losses across these membranes (Wendelaar Bonga 1993). Any damage to the environmental barriers of freshwater fish tends to increase the water influx and results in a dilution of body fluids (Stoskopf 1993). During feeding, some water is inevitably swallowed and enters the intestinal tract. The loss of surface cells of the intestinal epithelium which occurs during the merogonic and gamogonic development of Goussia carpelli (Jendrysek et al. 1994) means that more of this ingested water will be absorbed. This could therefore be regarded as damage to the environmental barrier. Ion losses were observed, for example, as a stress-related depression in $\mathrm{Na}^{+}$and $\mathrm{Cl}^{-}$levels in lake trout Salvelinus namaycush subjected to prolonged crowding stress (McDonald \& Millican 1992). Stress-related changes of serum sodium levels in fish are thought to be induced by elevated catecholamine release which causes dilation of gill vessels and increased blood flow through gill lamellae. In freshwater fish, an increased blood flow through gill vessels enhances the ion exchanges over gill lamellae and thus results in a net $\mathrm{NaCl}$ loss (Wendelaar Bonga 1993). In our experiments, a slight reduction of serum osmolarity and a clear depression of serum $\mathrm{Na}^{+}$level were observed in infected carp with the development of the coccidia. This was most prominent during gamogony and oocyst formation, and the fish recovered from the depression of electrolyte levels after most parasites had been excreted. The question of whether the dilution of the body fluids was caused by an increased influx of water across the damaged gut lining or by elevated ion loss over permeable surfaces remains to be investigated.

Sodium is the major cation in the blood of fishes and together with chloride contributes most to the serum osmolarity (McDonald \& Millican 1992). McDonald \& Millican (1992) have argued that electrolyte measurements are more reliable than measurement of serum osmolarity and that osmotic effects can be monitored by $\mathrm{Na}^{+}$and $\mathrm{Cl}^{-}$measurements. In the present study, a hemodilution in G. carpelli-infected carp was observed more clearly by means of $\mathrm{Na}^{+}$concentrations than by means of serum osmolarity measurements.

Serum potassium levels in carp with Goussia carpelli coccidiosis increased during gamogony, oocyst formation, and oocyst shedding. In fish, plasma $\mathrm{K}^{+}$levels are relatively unaffected by increased branchial electrolyte permeability. Less than $2 \%$ of the total body $\mathrm{K}^{+}$ are contained in extracellular fluids (Eddy 1985). Consequently, any branchial influx or efflux can be buffered by transfers from or to intracellular compartments (McDonald \& Millican 1992). In fish, elevated plasma $\mathrm{K}^{+}$levels have been observed after extensive exercise (Graham et al. 1982) or after substantial cell death. In the present study, elevated serum $\mathrm{K}^{+}$levels were measured in carp when oocysts were released from the tissue into the gut lumen and considerable numbers of intestinal cells were disrupted or necrotized. In cattle with acute coccidiosis increased serum $\mathrm{K}^{+}$levels also were related to extensive disruption of intestinal epithelium cells (Fitzgerald 1967).

During the development of Goussia carpelli, the level of serum proteins decreased significantly in the blood of infected carp. This decrease was seen in the level of total serum proteins, in albumins, and in globulin fractions as well. It peaked during oocyst formation of the parasite. In fish, alterations of serum protein levels are mainly caused by changes in blood volume, and a decrease in serum protein is considered to indicate plasma hydration (McDonald \& Millican 1992). Reductions in serum protein level were found with, for example, severe stress, prolonged starvation (McDonald \& Millican 1992), and with alterations in permeability of environmental barriers (Olson 1992). In avian coccidiosis, a decrease of serum proteins was considered to reflect a protein loss due to blood loss into the gut lumen, extensive tissue destruction, and malabsorption (Ruff 1986). In carp with G. carpelli coccidiosis, the reduction of serum protein levels might reflect a combined effect of protein losses caused by tissue destruction, which occurs during gamogony and oocyst formation (Kent \& Hedrick 1985, Jendrysek et al. 1994), malabsorption, and starvation, which was observed in the present study during parasite development.

In mammalian and avian coccidiosis, blood loss into the gut lumen provokes a decrease in packed blood cell volume which often is accompanied with a fall in plasma electrolytes and proteins (Ruff \& Allen 1990). In rabbits infected with Eimeria intestinalis, hemodilution and a decrease in plasma sodium, potassium and chloride was recorded at the peak of infection (Peeters et al. 1984). In the present study, substantial blood loss could not be discerned in carp infected with Goussia 
carpelli. The number of red blood cells and the packed cell volume did not change during the development of the parasite even though Jendrysek et al. (1994) observed a destruction of intestinal epithelium and rupture of blood vessels in such carp at the peak of infection. With respect to our findings, the blood loss seen in histological preparations appeared not to be substantial or could be regenerated quickly.

During gamogony and oocyst formation of Goussia carpelli, Lom \& Dykova (1992) and Jendrysek et al. (1994) observed a leukocytic infiltration into affected gut tissue. Infiltrating cells, mainly granulocytes and phagocytes indicated the induction of inflammatory processes in association with tissue damage and invading bacteria. An induction of inflammatory processes during acute intestinal coccidiosis of carp also could be discerned from differential WBC counts. In the present study, a granulocytosis was observed in the blood of infected carp at the peak of infection on Days 11 and 14 PE. In mammalian and avian coccidiosis, inflammation in the intestine is a common phenomenon and is accompanied by structural and physiological changes which are inimical to parasite development (Wakelin \& Rose 1990). Compared with birds or mammals, carp showed a mild reaction to the severe tissue damage caused by the coccidia (Jendrysek et al. 1994). In the present study, clinical symptoms and changes in WBC populations in the peripheral blood were limited to a few days at the peak of the infection and again indicated a mild reaction of carp on intestinal coccidiosis. This could be explained by a low tendency of fishes to develop acute inflammatory reactions. Ferguson (1989) argued that this might be explained by retarded biochemical reactions due to the poikilothermic physiology of fishes.

In cell suspensions prepared from the pronephros and the intestine of Goussia carpelli-infected carp, the number of surface immunoglobulin positive lymphocytes increased with the development of the parasite and remained elevated (Steinhagen \& Rombout 1994). This was assumed to reflect the induction of local and systemic immune responses in parasitized carp. In the present study, a leucocytosis was observed in $G$. carpelli-infected carp on Days 21 and 28 PE and gave further indication for the induction of immune processes in parasitized carp.

In conclusion, the present study has shown that the ion and protein balance of carp is influenced by an infection with the enteritic Goussia carpelli. Ion loss and hydration of blaod plasma, which is indicated by a decrease of serum $\mathrm{Na}^{+}$and protein level, have to be regarded as serious osmotic challenges to affected carp. Furthermore, the loss of surface cells of the intestinal epithelium allowed the invasion of opportunistic bacteria, which causes a further challenge to parasitized carp. With respect to these observations, the infection of carp with G. carpelli should be taken as a serious pathogen for stressed or juvenile fish.

Acknowledgements. We thank Dr R. Mischke, D. Kemmesies, U. Rabe, and B. Schwerdt, Hannover, for excellent technical help and fruitful discussions. Mr S. H. Leenstra, Wageningen Agricultural University, The Netherlands, generously provided fertilized carp eggs. This research was financially supported by a grant from the Niedersächsische Minister für Wissenschaft und Kunst.

\section{LITERATURE CITED}

Doflein F, Reichenow E (1953) Lehrbuch der Protozoenkunde, 6 th edn. Fischer Verlag, Stuttgart

Eddy EB (1985) Uptake and loss of potassium by rainbow trout (Salmo gairdneri) in fresh water and dilute sea water. J Exp Biol 118:277-286

Ferguson HW (1989) Systemic pathology of fishes. Iowa State University Press, Ames

Fitzgerald PR (1967) Deviations in serum proteins associated with Eimeria bovis infections in calves. J Parasitol 50: $42-48$

Graham MS, Wood SM, Turner JD (1982) The physiological responses of the rainbow trout to strenuous exercise: interactions of water hardness and environmental acidity. Can J Zool 60:3153-3164

Gregory MW (1990) Pathology of coccidial infections. In: Long PL (ed) Coccidiosis of man and domestic animals. CRC Press, Boca Raton, FL, p 235-261

Houston AH (1990) Blood and circulation. In: Schreck CB, Moyle PB (eds) Methods for fish biology. American Fisheries Society, Bethesda, MD, p 273-334

Ivassik VM, Kulakovskaya OP (1959) On the carp coccidiosis. Zool Zh 38:1746-1750 (in Russian)

Jendrysek S, Steinhagen D, Drommer W, Körting W (1994) Carp coccidiosis: intestinal histo- and cytopathology under Goussia carpelli infection. Dis Aquat Org 20:171-182

Kent ML. Hedrick RP (1985) The biology and associated pathology of Goussia carpelli Leger and Stanovitch) in goldfish Carassius auratus (Linnaeus). Fish Pathol 20: $485-494$

Kocylowski B, Zelazny J, Antychowitz J, Pancyk J (1976) Incidence of carp coccidiosis and its control. Bull Vet Inst Pulawy 20:12-17

Lom J, Dykova I (1992) Protozoan parasites of fishes. Developments in aquaculture and fisheries science, Vol 26 Elsevier, Amsterdam

McDonald DG, Millican CL (1992) Chemical properties of the blood. In: Hoar WS, Randall DJ, Farrel AP (eds) Fish physiology, Vol 11, Part B. The cardiovascular system. Academic Press, San Diego, p 55-133

Olson KR (1992) Blood and extracellular fuid volume regulations: role of the renjn-angiotensin system, kallikein-kinin system, and atnal natriuretic petides. In: Hoar WS, Randall DJ, Farrel AP (eds) Fish physiology, Vol 11, Part B. The cardiovascular system. Academic Press, San Diego, p 135-254

Peeters JE, Charlier G, Antonie O, Mammerickx M (1984) Clinical and pathological changes after Eimeria intestinalis infection in rabbits. Zentralbl Veterinärmed B 31:9

Ruff MD (1986) Reasons for inadaequate nutrient utilization during avian coccidiosis: a review. In: Mc Dougald LR, Joyner LP, Long PL (eds) Research in avian coccidiosis. Proceedings of the Georgia Coccidiosis Conference, 1985, 
University of Georgia, Department of Poultry Science, Athens, p 169

Ruff MD, Allen PC (1990) Pathophysiology. In: Long PL (ed) Coccidiosis of man and domestic animals. CRC Press, Boca Raton, FL, p 263-280

Schäperclaus W (1943) Die Darmcoccidiosen, insbesondere die Knötchencoccidiose des Karpfens. Z Fisch Hilfswiss 41:283-295

Steinhagen D, Hespe K, Körting W (1996) Karpfencoccidiose: Feldbeobachtungen und Infektionsexperimente mit Goussia carpelli. In: Hoffmann R, Bernoth EM (eds) Deutsche Veterinärmedizinische Gesellschaft, Fachgruppe Fischkrankheiten, Tagung Königswartha German Veterinary Medical Society, Gießen, p 111-116

Steinhagen D, Körting W (1988) Experimental transmission of Goussia carpelli (Leger \& Stankovitch, 1921; Protista: Apicomplexa) to common carp Cyprinus carpio L. Bull Eur Assoc Fish Pathol 8:112-113

Editorial responsibility: Managing Editor
Steinhagen D, Körting W (1990) The role of tubificid oligochaetes in the transmission of Goussia carpelli. J Parasitol $76: 104-107$

Steinhagen D, Rombout JHWM (1994) Response of Ig-positive cells to Goussia carpelli (Protozoa: Apicomplexa) infections in carp (Cyprinus carpio L.). Folia Parasitol 41: $173-176$

Stoskopf MK (1993) Clinical physiology. In: Stoskopf MK (ed) Fish medicine. Saunders, Philadelphia, p 48-57

Wakelin D, Rose ME (1990) Immunity to coccidiosis. In: Long PL (ed) Coccidiosis of man and domestic animals. CRC Press, Boca Raton, FL, p 281-306

Weichselbaum TE (1946) An accurate and rapid method for the determination of proteins in small amounts of blood, serum, and plasma. Am J Clinic Pathol 16:40-49

Wendelaar Bonga SE (1993) Endocrinology. In: Evans DH (ed) The physiology of fishes. CRC Press, Boca Raton, FL, p 469-502

Manuscript received: April 11, 1997

Revised version accepted: May 28, 1997 